\title{
Wide reproductive period of a long-distance migratory fish in a subtropical river, Brazil
}

\author{
Evoy Zaniboni-Filho, Josiane Ribolli, Samara Hermes-Silva and Alex P. O. Nuñer
}

Salminus brasiliensis is a potamodromous fish species that occurs in southern South American rivers. In spite of its ecological and economic relevance, information regarding the reproductive biology of $S$. brasiliensis is still scarce. This study used data from 18 years of continuous sampling in the Upper Uruguay River Basin, analyzing 718 adult fish (307 males, 243 females, 168 undefined) captured at different months of the year. The results showed that the reproductive timing for S. brasiliensis is wide in the Upper Uruguay River, with the occurrence of mature fish between the month of August and March and spawned individuals between July and May of the next year. These results were sustained by the increase of gonadal somatic relationship (GSR) from August. The reproductive timing of S. brasiliensis in the Upper Uruguay River may start between the middle winter and early spring (from late July to late September), and may extend until the late summer and middle fall (from the middle February to early May). These findings contribute to information on the general biology of S. brasiliensis and provide valuable knowledge to management programs and to conservation efforts of this fisheries resource.

Keywords: Dourado, Long-term study, Population parameters, Salminus brasiliensis, Uruguay River.

Salminus brasiliensis é uma espécie potamodroma que ocorre em rios da América do Sul. Apesar de sua importância ecológica e econômica, informações sobre a biologia reprodutiva de $S$. brasiliensis ainda são escassas. O presente estudo utilizou dados de 18 anos de amostragens contínuas na bacia do alto rio Uruguai, analisando 718 peixes adultos (307 machos, 243 fêmeas, 168 indefinidos) capturados em diferentes meses do ano. Os resultados mostraram que o período reprodutivo de S. brasiliensis é amplo na bacia do alto rio Uruguai, com a ocorrência de peixes maduros entre agosto e março, e de peixes desovados entre os meses de julho e maio do ano seguinte. A relação gonadossomática reforça essa observação, pois mostra um aumento a partir de agosto. O período reprodutivo de S. brasiliensis no alto rio Uruguai pode iniciar entre meados do inverno e início da primavera (entre final de julho e final de setembro), podendo se estender até o final do verão e meados do outono (entre meados de fevereiro e início de maio). Essas descobertas contribuem com informações sobre a biologia geral de S. brasiliensis e são relevantes para programas de gestão e para esforços de conservação desse recurso pesqueiro.

Palavras-chave: Estudos de longa duração, Dourado, Parâmetros populacionais, Rio Uruguai, Salminus brasiliensis.

\section{Introduction}

Teleosts show the most diverse reproductive strategies among the vertebrates (Munro, 1990). These strategies are often subjected to intense natural selection, in which the reproductive timing is one of the most important variables related to species life history and to the success of the next generation (Winemiller, 1989). The reproductive process constitutes the basis of the knowledge of the species life cycle (Chaves, Vazzoler, 1984) and can exhibit seasonal variations depending on the environment (Winemiller, 1993). In the Neotropical region, the reproductive timing of long-migratory species usually occurs between spring and summer, with greater intensity between November and
January (Gonçalves et al., 2006; Boncompagni Junior et al., 2013; Nunes et al., 2015). This period is associated with temperature (Reynalte-Tataje et al., 2012), precipitation, electrical conductivity and water level and flow increase (Welcomme, 1979; Vazzoler, 1996; Fernandes et al., 2009).

The Uruguay, Paraná and Paraguay rivers form the La Plata drainage basin, the second biggest watershed in the South American continent (Carolsfeld et al., 2003). The Uruguay River shows some characteristics that are absent in those other: the Uruguay River runs in subtropical and temperate latitudes with well-defined seasons, whereas most of the Paraná and Paraguay rivers are located in tropical latitudes with a climate basically hot and humid along the year (Agostinho et al., 2004). In addition, the rainy period,

Laboratório de Biologia e Cultivo de Peixes de Água Doce, Universidade Federal de Santa Catarina, Rod. SC 403, Caixa Postal 3532, 88066260 Florianópolis, SC, Brazil. (EZF) evoy@lapad.ufsc.br (corresponding author), (JR) josianeribolli@gmail.com, (SHS) samara@lapad.ufsc.br, (APON) alex.nuner@ufsc.br 
concentrated in the spring and summer, is seasonally marked in the drainage basins of the Paraná and Paraguay rivers, while rain peaks can occur at different seasons throughout the year in the Upper Uruguay River Basin (Zaniboni-Filho, Schulz, 2003). Migratory species exhibit a high degree of synchronization between the reproduction event and favorable environmental conditions (Winemiller, Jepsen, 1998), since flood is a key factor for the timing of reproduction even in the absence of a clear dry and rainy season (Agostinho et al., 2004; Oliveira et al., 2015).

The dourado Salminus brasiliensis (Cuvier, 1816) is a long-distance potamodromous fish widely distributed in southern South American basins (Froese, Pauly, 2015). It is the largest Bryconidae (cited as Characidae) species found in the La Plata Basin (Morais Filho, Schubart, 1955) and one of the biggest fish predators of the system, playing an important ecological role structuring the prey community. Additionally, the species has a prominent position in commercial and recreational fisheries.

In spite of this importance, few studies investigated the reproductive timing of $S$. brasiliensis in wild populations (Vazzoler, 1996; Barbieri et al., 2001; Villares Júnior, 2014), concluding that it occurs between late spring (late November) and summer (Dec and Jan), in regions where rainfall peak is well-defined. However, a study performed in the Upper Uruguay River Basin observed mature and spent individuals out of the reproductive timing observed in other river basins (Machado, 2003). Although S. brasiliensis occurs throughout the La Plata Basin, its reproductive timing appears to be different Upper Uruguay River, probably due to the lack of well-defined seasons of drought and rain, typical of other Neotropical basins. Southern Brazil is located in a climate transitional zone, under the influence of polar and tropical atmospheric systems that provide rainfall distribution throughout the year; besides, the region lacks well-defined dry seasons (Sartori, 2003). Due to occurrence of climatic anomalies, such as "El Niño" and "La Niña" (Sartori, 2003), these atmospheric systems can produce great variability of rainfall in the region, such as long droughts or great floods.

Moreover, studies focusing the Uruguay River Basin used scientific information from studies carried out in tropical watersheds as references. Valuable information was also highlighted by Ribolli et al. (2016), who identified temporal population structure among $S$. brasiliensis populations in the Upper Uruguay River during the reproductive timing. The authors identified temporal genetic differentiation between adult fish collected in the early spring (late September) and the late summer (middle February), which corresponds to the beginning and end of the reproductive timing. This finding motivated the present investigation on the reproductive dynamics of $S$. brasiliensis based on longterm data in the Upper Uruguay River Basin. Information about the reproductive timing of this species will contribute to the knowledge about their reproductive biology and issues related to its life history. Our main objectives in this study were i) to characterize the reproductive timing and its multi-year variation and ii) to evaluate population parameters of $S$. brasiliensis, in the Upper Uruguay River Basin along 18 years of study.

\section{Material and Methods}

Study area. The studied region comprises an area with approximately $580 \mathrm{~km}$ of river, including the main tributaries of theUpper Uruguay River, such as Chapecó, Jacutinga, Rancho Grande, and Rio do Peixe rivers, and its formers (Canoas and Pelotas rivers). In this region, the Uruguay River runs in an embedded valley, with a marked inclination and without floodplains; the tributaries are usually short and have waterfalls, which may hinder the movement of fish. The rainfall is distributed throughout the year, with peaks occurring in any season, which may cause rapid and brief flood pulses (Zaniboni-Filho, Schulz, 2003; Sartori, 2003). Data of mean precipitation (mm), obtained from the Metereological Data Base for Teaching and Research/ National Institute of Meteorology (BDMEP/ IMET) from the Iraí Station, show the rainfall distribution along the sampling period (Fig. 1).

Sampling and data processing. The data used in this study were collected from April 1996 to February 2014, joining samples obtained in scientific fishing surveys with samples performed by local fishermen. Samples were collected at 36 sites (Fig. 2) distributed throughout the study area: 23 scientific sampling sites and 13 sites used by local fishermen.

In the scientific fishing, a set of gill and trammel nets were used, with mesh sizes ranging from 1.5 to $8.0 \mathrm{~cm}$ between adjacent knots; gillnets height ranging from 1.4 to $8.0 \mathrm{~m}$ and the length ranging from 10 to $120 \mathrm{~m}$. Nets were placed in the evening and removed in the following morning, being exposed for approximately $12 \mathrm{~h}$. All the fish captured were weighed (in grams) and measured (total length in $\mathrm{cm}$ ), and some were separated for gonadal analysis that included macroscopic identification of sex and gonadal maturation stages, and the weighing of the gonads $(0.01 \mathrm{~g})$.

The sampling performed by local fishermen used additional fishing equipment, such as fishing reels, hook and line, and gillnets with mesh sizes ranging from 8 to $15 \mathrm{~cm}$ between knot to knot. All fishermen were properly instructed for correct species identification, recording of weight $(\mathrm{g})$ and total length $(\mathrm{cm})$ data, and for preserving fish viscera in a properly labeled $10 \%$ formalin solution. In the laboratory, the gonads were separated, weighed $(0.01 \mathrm{~g})$ and the stages of maturation were identified. Due to formalin fixation, gonads weights were corrected, considering a $2.0 \%$ loss of their fresh weight, following Costa (2003).

Research was conducted following Animal Care Protocol PP00788, and the vouchers of S. brasiliensis were deposited in the fish collection of Museu de Zoologia da Universidade Estadual de Londrina (MZUEL 7912). 


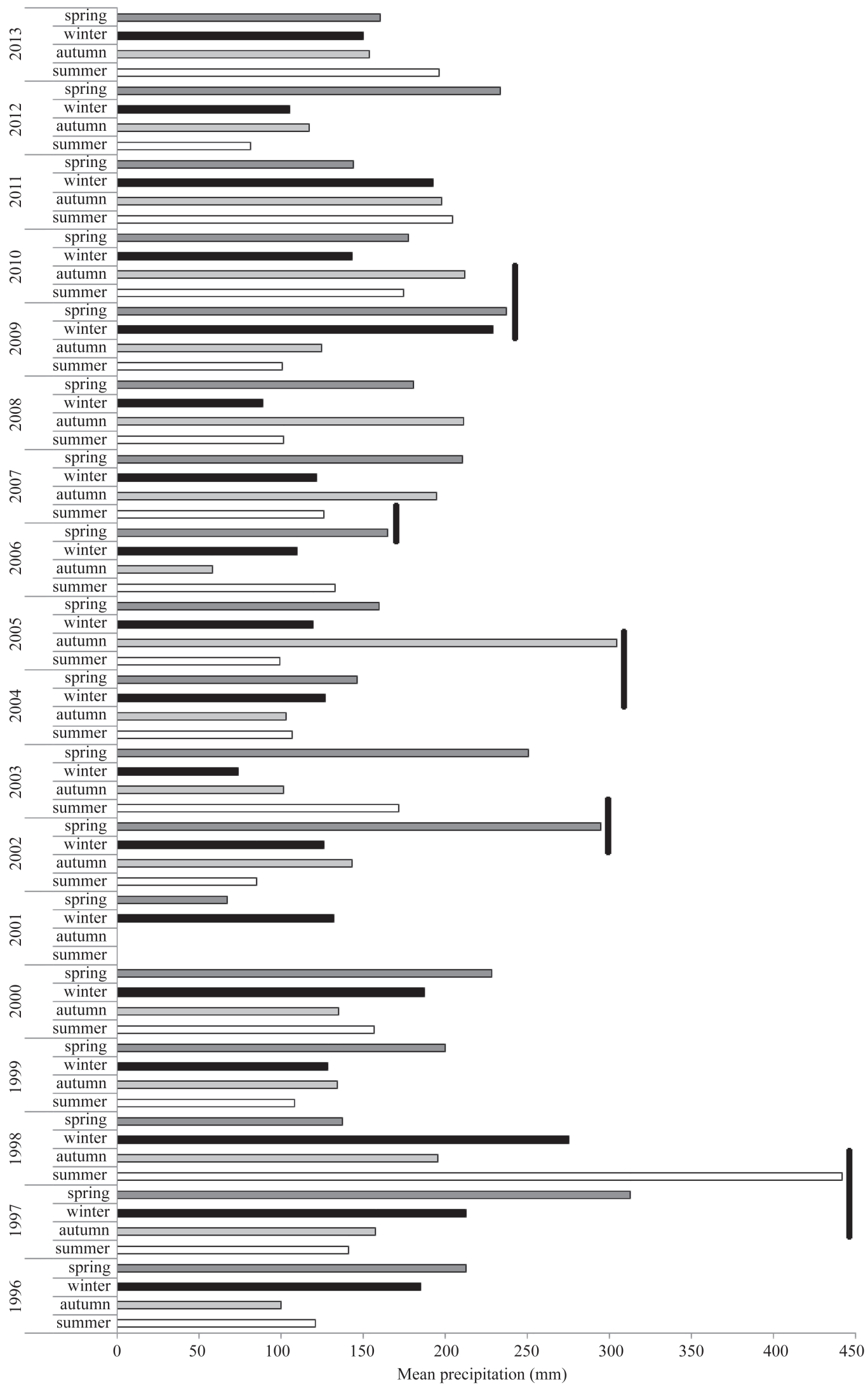

Fig. 1. Mean seasonal precipitation (mm) during the study period (1996-2013). Data obtained from the Meteorological Data Base for Teaching and Research/ National Institute of Meteorology (BDMEP/ IMET) from the Iraí Station. The vertical black bars indicates the occurrence of El Niño events ( 1997-1998, 2002-2003, 2004-2005, 2006-2007, 2009-2010). 


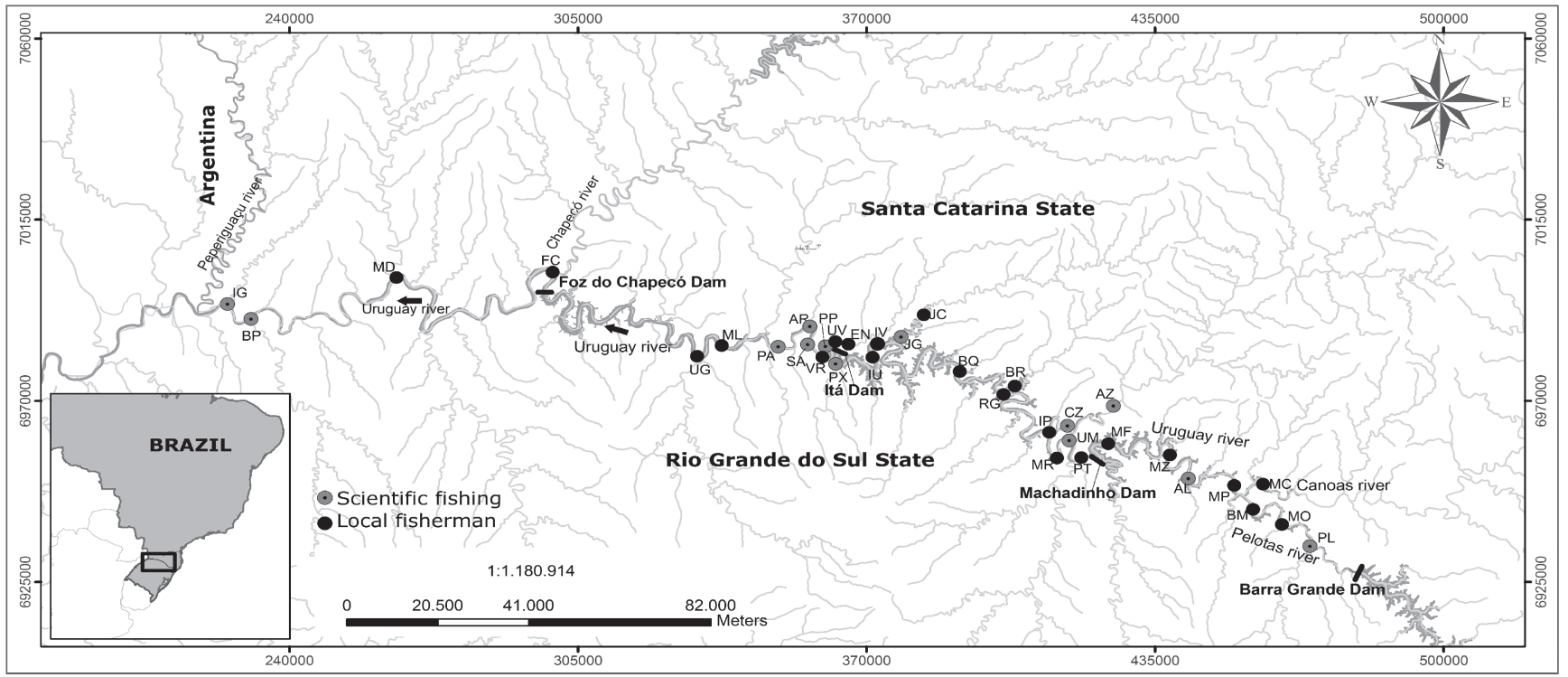

Fig. 2. Study area in the Upper Uruguay River Basin, border between Santa Catarina and Rio Grande do Sul States, Southern Brazil. The black (scientific fishing) and gray (fishermen fishing) dots indicate the sampling sites of Salminus brasiliensis.

Data analysis. The population structure was evaluated by sex ratio and total length $(\mathrm{cm})$. The absolute frequency of males and females in the whole sampling period were analyzed with a chi-square test to determine the sex ratio, testing the null hypothesis that it is independent from length classes. When this hypothesis was not accepted a complementary chi-square was applied, grouping length data in two classes to test the null hypothesis that independence occurred until the limit of a specific length. The Sturges' rule was applied to determine the number of intervals in which total length distribution was split (Sturges, 1926).

The length-weight relationship (LWR) was estimated using the model $\log W=\log a+b \log L t$, where $\mathrm{W}$ is the weight $(\mathrm{g}), \mathrm{Lt}$ is the total length $(\mathrm{cm})$, and $a$ and $b$ are the linear equation coefficients. The condition factor $(\mathrm{K})$ was calculated for adult males and females separately using the formulae $\mathrm{K}$ $=\mathrm{Wt} \times 100 / \mathrm{Lt}^{\mathrm{b}}$ where $\mathrm{Wt}$ corresponds to the fish weight $(\mathrm{g})$, $\mathrm{Lt}$ to fish total length $(\mathrm{cm})$ and the $b$ value is from the LWR; the non-parametric Kruskal-Wallis test was applied to verify if differences between $\mathrm{K}$ at different sampling months exist, followed by a post-hoc comparison of the groups mean ranks when necessary (Statistica 7.0 Software).

Reproductive dynamics. Analysis of the reproductive dynamics of $S$. brasiliensis was based on the gonadal maturation stages of adults and the temporal distribution of the gonadal somatic relationship (GSR). The temporal distribution of GSR was also evaluated according to the presence or not of the climatic phenomena ENSO (El Niño-Southern Oscillation) throughout the studied years. The GSR was calculated by the formulae $\mathrm{GSR}=(\mathrm{Wg} / \mathrm{Wt}) \times 100(\mathrm{Wg}=$ gonad weight, in $\mathrm{g}$; $\mathrm{Wt}=$ total fish weight, in $\mathrm{g}$ ), separately for males and females. Macroscopic analysis of gonadal stages was performed in the field following Vazzoler (1996) categories: Immature (I), Maturing (Mn), Mature (M), Spent (S), and Regression (Rg).
The record of the presence of climatic events throughout the study period were obtained from the National Oceanic and Atmospheric Association (NOAA, 2015), and were based on the water temperature of the Pacific Ocean: water temperatures warmer than normal were considered an El Niño period.

\section{Results}

Population structure. During the study period $718 \mathrm{~S}$. brasiliensis were captured: 284 collected in 23 scientific fishing sites and 434 captured by 13 fishermen distributed along the study area. The highest fish capture (36.3\%) occurred in two sampling sites located in the Uruguay River, in a section situated just below the Itá Dam (26.0\% captured by fisherman; $10.3 \%$ by scientific fishing). From the total number captured, 307 were males $(62.41 \pm 9.04$ $\mathrm{cm} ; 3,121.56 \pm 1,197.76 \mathrm{~g}$ ) (mean \pm standard deviation), 243 were females $(65.37 \pm 11.75 \mathrm{~cm} ; 4,099.60 \pm 2,640.44 \mathrm{~g})$ and 168 were identified as immature (juvenile fish whose sex was not possible to identify). The largest fish captured was a female with $28,500 \mathrm{~g}$ and $100.5 \mathrm{~cm}$, and the smallest a juvenile with $300 \mathrm{~g}$ and $20.0 \mathrm{~cm}$.

Sex ratio was dependent on the length classes $\left(\chi^{2}=33.87\right.$; $\mathrm{gl}=8 ; \mathrm{P}<0.01)$; a higher proportion of males were observed in length classes lower than $75.5 \mathrm{~cm}$, while for individuals larger than $75.6 \mathrm{~cm}$ there was a greater proportion of females $(\chi 2=27.28 ; \mathrm{gl}=1 ; \mathrm{P}<0.01)$ (Fig. 3).

The LWR was established from the linear equation for males and females separately (Tab. 1). The value of the $b$ parameter estimated was $3.09\left(\mathrm{R}^{2}=0.87\right)$ for females and $2.71\left(\mathrm{R}^{2}=0.79\right)$ for males. No significant difference was found in the distribution of $\mathrm{K}$ values for females and for males, although remarkable changes were observed throughout the year (Fig. 4). 


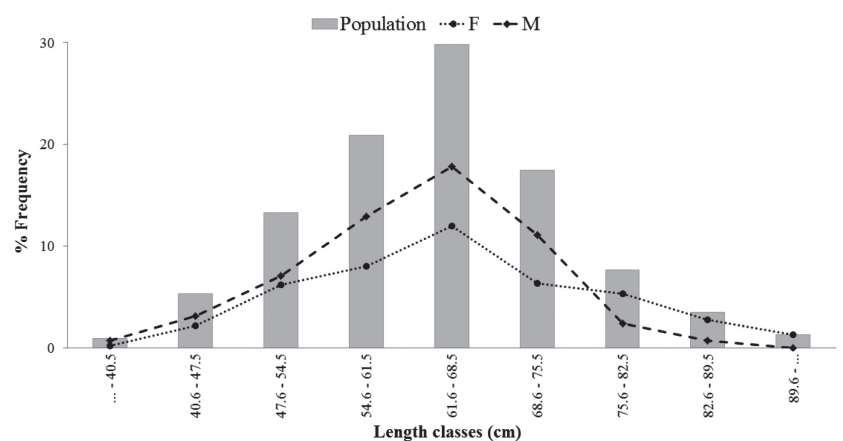

Fig. 3. Frequency distribution of Salminus brasiliensis population by length classes (bars) and grouped by sex (lines). From the Upper Uruguay River between April 1996 and February 2014.

Tab. 1. The weight/length relationship for females and males of Salminus brasiliensis in the Upper Uruguay River Basin. Between April 1996 and February 2014. $n=$ sample size, $\mathrm{L}=$ total length $(\mathrm{cm})$.

\begin{tabular}{lccccc}
\hline Sex & $\mathrm{n}$ & $\mathrm{L}(\min -\max )$ & $b$ & $a$ & $R^{2}$ \\
\hline Females & 243 & $38.0-100.5$ & 3.0916 & -2.0516 & 0.8716 \\
Males & 307 & $33.5-86.0$ & 2.7103 & -1.3974 & 0.7890 \\
\hline
\end{tabular}

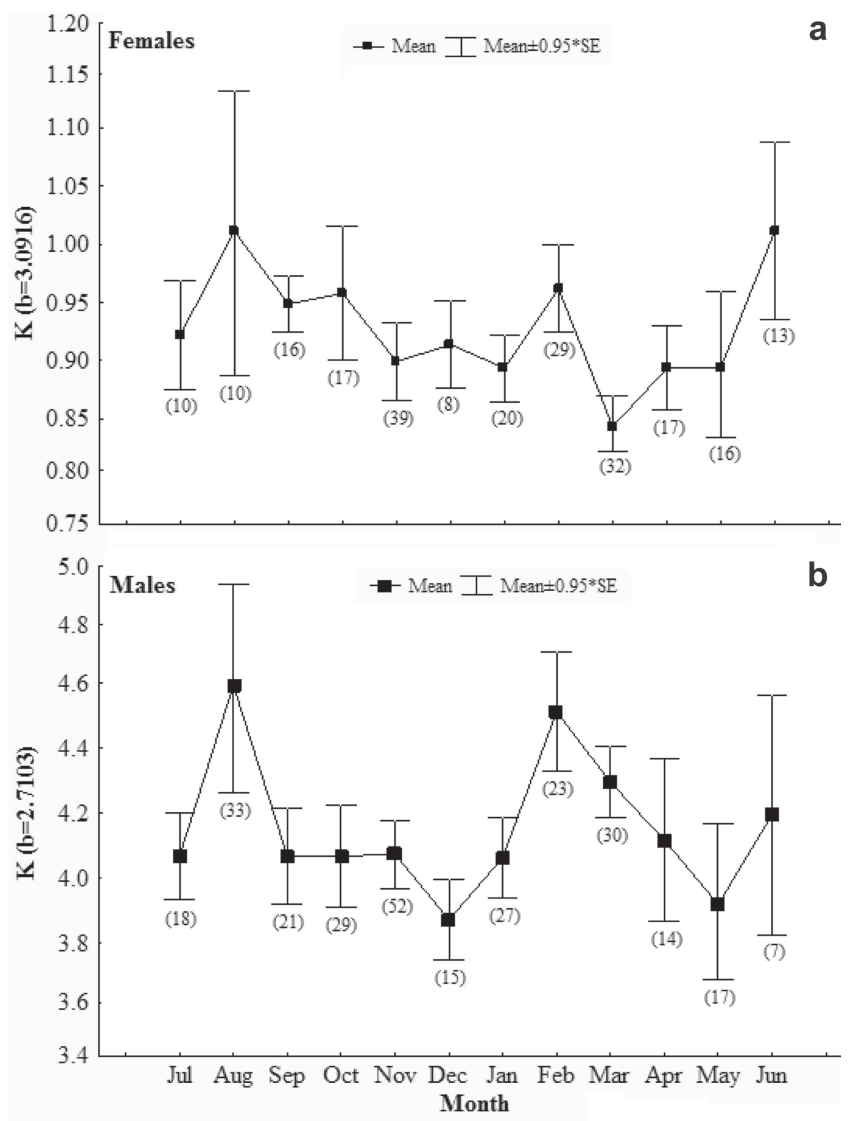

Fig. 4. Allometric condition factor (mean \pm SE) of females and males of Salminus brasiliensis at different sampling months in the Upper Uruguay River (between April 1996 and February 2014). The number of individuals used in each month is in parenthesis. a. Females; b. Males.
Reproductive dynamics. The gonadal maturation analyses included 242 females and 305 males. Of the total females analyzed, it was possible to identify 26 females in the spent stage, 148 maturing, 46 mature, five in regression, and 17 immature. For males, there were 13 spent, 209 maturing, 62 mature, two in regression and 19 immature.

The average GSR was 6.66 ( 0.39 to 20.82) for females and $1.66(0.21$ to 7.57$)$ for males. Regarding the reproductive period, maturing males and females were observed in all sampling months. Mature females occurred between August and March, while spent individuals were captured between July and May (Fig. 5a). Individuals in regression were found in September and between January and May. An increase in the GSR was observed for females starting in August and extending until March, at which point there was a sharp drop (Fig. 5a). Males also showed a long reproductive period, with mature individuals found from July to March, spawned individuals found between November and May, and individuals in the regression stage found in November, February and May (Fig. 5b).

The temporal distribution of females GSR according to the presence or not of ENSO revealed two peaks of GSR during years with the presence of ENSO, from August to November and from February to April. While, in years without the influence of this climatic phenomena, the GSR peak occurred only between December and February (details in Fig. S1 - Available only as online supplementary file accessed with the online version of the article at http://www.scielo.br/ni). The temporal distribution of males GSR also showed an increase in GSR starting from August during years with the presence of ENSO.

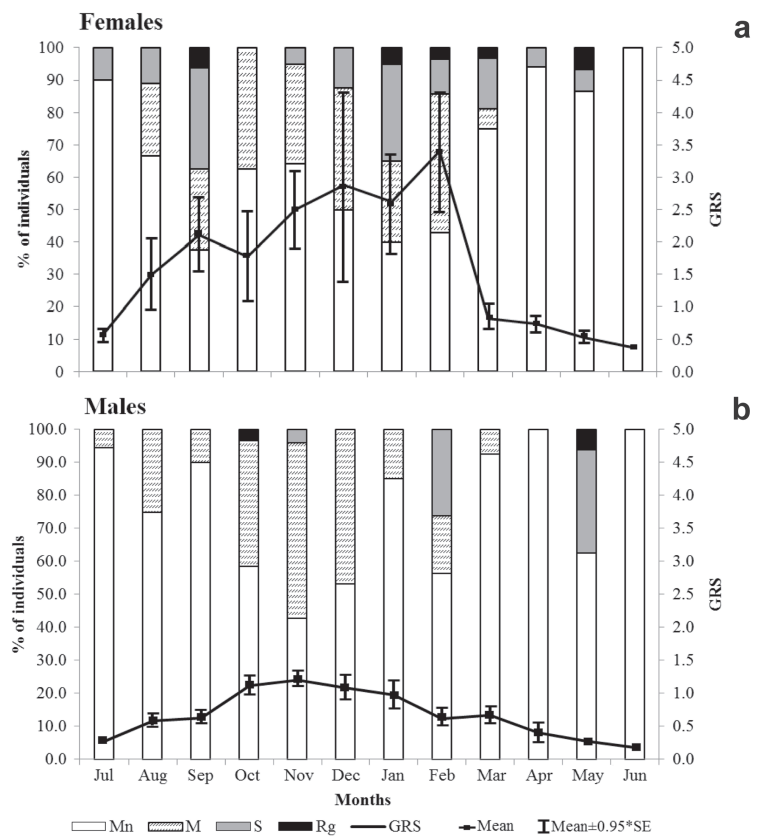

Fig. 5. Monthly distribution of the gonadal maturation stages and the average gonadal somatic relationship ( \pm SE) for females and males of Salminus brasiliensis from the Upper Uruguay River between April 1996 and February 2014. a. Females; b. Males. I = Immature; $\mathrm{Mn}=$ Maturing; $\mathrm{M}=$ Mature; $\mathrm{S}=$ Spent; $\mathrm{Rg}=$ Regression. 


\section{Discussion}

The data of this long-term study showed a wider reproductive timing for $S$. brasiliensis in the Upper Uruguay River Basin that may start in middle winter and early spring, and extends until the end of the summer and middle fall. For both sexes, the highest GSR values occurred between September and February; however, a gonad size increase was observed starting in August, which included the presence of mature and/or spent individuals.

The population of $S$. brasiliensis showed a sex ratio dependent on length classes, with a predominance of males in smaller classes and a predominance of females in the larger ones. In fish stocks, this sex ratio can vary throughout the individual's life cycle due to different factors, such as mortality and growth, or to differential behavior, which can act differently on each sex (Vazzoler, 1996). In general, most Neotropical fish species show a sex ratio of 1:1 (Lowe-McConnell, 1987) when the whole population is evaluated; however, variations of this ratio can occur when the analysis considers different length classes or maturation stages. The predominance of females in the higher length classes is related to an accelerated growth rate (Vazzoler, 1996; Barbieri et al., 2001), a strategy linked to their reproductive behavior (Veregue, Orsi, 2003) and with evolutionary aspects of the species, where larger females have greater abdominal cavities and, therefore, can produce a much larger number of offspring. Females of $S$. brasiliensis (cited as $S$. maxillosus) from Mogi-Guaçu River and the Corumbá Reservoir, both in the Upper Paraguay River Basin, also exhibited greater sizes than males (Barbieri et al., 2001; Dei Tos et al., 2009).

The LWR for S. brasiliensis in this study showed different allometric coefficients between sexes, with higher values for females. However this difference falls within expected values found for several freshwater Neotropical species (Giarrizzo et al., 2011; Freitas et al., 2017). The LWR variation can be associated with particular populations, and with season and annual changes in environmental conditions (Froese, 2006). The value of the $b$ parameter was $>3$ for females and $<3$ for males of $S$. brasiliensis, which falls within the expected range for most freshwater fish species $(2.5<\mathrm{b}>3.5$; Froese, 2006; Froese et al., 2011).

The adult population of $S$. brasiliensis from the Upper Uruguay River showed remarkable changes in the individual's condition factor throughout the year. This parameter is used to indicate the physiological condition of fish in its environment (Lima Junior et al., 2002), and its variation is used as additional information in seasonality studies of feeding and reproduction (Zardo, Behr, 2015), indicating reduction in fish feeding and/ or a large reproductive period. In this way, as the condition factor of each fish is also affected by the gonad weight, the presence of individuals at different maturity stages in the same month can cause an increase in the monthly average dispersion of $\mathrm{K}$ values. When fish show a short reproductive period, as reported for $S$. brasiliensis in the Paraná River (Barbieri et al., 2001) and for matrinxã Brycon orthotaenia Günther, 1864
(Gonçalves et al., 2006), it is observed that the GSR increase is directly associated with the condition factor values. A similar situation occurs in fish with a marked seasonality in feeding rate, such as the tambaqui Colossoma macropomum (Cuvier, 1816) (Villacorta-Correa, Saint-Paul, 1999) and the pacu-toba Mylossoma cf. duriventris (Cuvier, 1818) (Goulding, 1980), two Amazonian species in which the condition factor is directly influenced by fat deposition resulting from intense feeding during a specific period. Thus, fish caught in the same period tend to have similar physiological status, both related to fat or gonadal maturity stage, or even both.

Despite the relevance of $S$. brasiliensis, biological information related to the reproductive timing in the Upper Uruguay River had not yet been defined; references for this species are still based on information gathered in other basins. For the vast majority of long-migratory fish, ecological factors (e.g., increase of temperature, photoperiod, and river level) play an important role in reproductive success (Lowe-McConnell, 1964; Welcomme, 1979; Agostinho et al., 2004; ReynalteTataje et al., 2008). According to Vazzoler (1996), most species with long-distance migratory patterns and total spawning behavior show a well-marked reproductive period, between November and February. For Pseudoplatystoma corruscans (Spix, Agassiz, 1829) found in the São Francisco River, the reproductive timing occurs between October and January, a season correlated with rain increase and its associated changes (Brito, Bazzoli, 2003). The same relationship between the reproductive period and precipitation was observed for Salminus franciscanus Lima, Britski, 2007, for which the beginning of the reproductive period and an increase in the GSR occur in October, coinciding with the beginning of the rainy season in the São Francisco River Basin (Freitas et al., 2013). In the same watershed, Gonçalves et al. (2006) also found that the reproductive period of the migratory fish $B$. orthotaenia occurs in the same period, between October and January. Salminus brasiliensis (cited as $S$. maxillosus) from the Upper Paraná River show a reproductive period between October and January (Vazzoler, 1996), similar to that observed for S. franciscanus from the São Francisco River (Freitas et al., 2013).

The reports with long-migratory Neotropical fish suggested the occurrence of reproductive timing between November and February, with the higher frequency of spawns between November and January. This study found a wider S. brasiliensis breeding season, and it is important to emphasize that mature and spent females were found between July and May, and a GSR increase was observed starting in August. Additionally, mature males were found between July and March and spent males were observed between November and May. The earlier start of the $S$. brasiliensis breeding season found in this study may be associated with the characteristics of the region. Ribolli et al. (2016) identified different genetic populations of S. brasiliensis temporally structured in the upper rio Uruguay. This structure is probably a consequence of the presence of different reproductive groups. As the region is situated in a Subtropical region, it has distinct hydrological peculiarities that are absent in the other Brazilian rivers that compose the La Plata Basin and the basin 
of São Francisco River. In tropical regions as the Upper Paraná and Tocantins rivers, for example, rainfall is marked by a rainy season between October to March (Agostinho et al., 2004; Lima et al., 2016). While the rainy season occurs in spring and summer in these watersheds, in southern Brazil (i.e., Uruguay River Basin) the rain is distributed along the year, with rain peaks occurring even in winter (Zaniboni-Filho, Schulz, 2003; Sartori, 2003), closely matching the beginning of S. brasiliensis reproductive activity.

This is the first long-term study that addresses the reproductive timing of a Neotropical long-migratory fish. The wider reproductive period found to $S$. brasiliensis may be expected when analyzing 18 years of data in $580 \mathrm{~km}$ of river, compared to studies that are restricted to one or two years. Data restricted to single years (e.g., one breeding season) may not detect changes and peculiarities in the reproductive timing because variations can be caused by ecological reasons or also associated with climatic events, such as El Niño (ENSO). El Niño is responsible for producing distinct rainfall patterns (more rain) in the rio Uruguay compared with other Brazilian watersheds (usually drier). During the ENSO years, mature and spent females were found in two distinct periods, between August-November and February-April (details in Fig. S1 Available only as online supplementary file accessed with the online version of the article at http://www.scielo.br/ni). In such periods, the frequency and variability of rainfall were above average in southern Brazil, Uruguay and northeastern Argentina (Pisciottano, 1994; Grimm et al., 1998). This higher frequency of rainfall prior to spring/summer can stimulate the precocious reproductive migration and reproduction of $S$. brasiliensis in this region.

This study suggests that S. brasiliensis in the Upper Uruguay River shows a reproductive timing wider than reported in other rivers of the La Plata Basin. Due to this finding, special attention must be given to the establishment of actions for stock conservation, especially in regions where it is considered an endangered species (Marques et al., 2002). In addition, information on the biological and reproductive aspects of $S$. brasiliensis can support effective decisions for the conservation and maintenance of this species. We hope these results will encourage new long-term studies with other migratory species, as it is possible that wider reproductive periods might not have been detected yet due to restricted sampling designs.

\section{Acknowledgments}

The authors acknowledge CAPES, CNPq, FAPESC, Engie (Tractebel Energia), Consórcio Itá and Consórcio Machadinho for financial support. EZF and APON acknowledge research productivity grants from CNPq. JR and SHS acknowledge scholarships provided by Programa Nacional de PósDoutorado PNPD/CAPES. We are grateful to the technicians from LAPAD, to local fishermen for their data collection and to Gianfrancisco Schork, for his important contribution with data sorting and to two anonymous reviewers for their valuable suggestions on the manuscript.

\section{References}

Agostinho AA, Gomes LC, Veríssimo S, Okada EK. Flood regime, dam regulation and fish in the Upper Paraná River: effects on assemblage attributes, reproduction and recruitment. Rev Fish Biol Fish. 2004; 14(1):11-19.

Barbieri G, Salles FA, Cestarolli MA. Growth and first sexual maturation size of Salminus maxillosus Valenciennes, 1849 (Characiformes, Characidae), in Mogi Guaçu river, state of São Paulo, Brazil. Acta Sci. 2001; 23(2):453-59.

Boncompagni Júnior O, Normando FT, Brito MFG, Bazzoli N. Reproductive biology of Prochilodus argenteus Agassiz, 1829 (Pisces: Prochilodontidae) in São Francisco River, Brazil. J Appl Ichthyol. 2013; 29(1):132-38.

Brito MFG, Bazzoli N. Reproduction of the surubim catfish (Pisces, Pimelodidae) in the São Francisco River, Pirapora Region, Minas Gerais, Brazil. Arq Bras Med Vet Zootec. 2003; 55(5):624-33.

Carolsfeld J, Harvey B, Ross C, Baer A, editors. Migratory Fishes of South America: biology, fisheries and conservation status. Victoria, Canada: World Fisheries Trust; International Development Research Centre; World Bank; 2003.

Chaves PTC, Vazzoler G. Aspectos biológicos de peixes amazônicos. III. Anatomia microscópica do esôfago, estômago e cecos pilóricos de Semaprochilodus insignis (Characiformes: Prochilodontidae). Acta Amazonica. 1984; 14(3-4):343-54.

Costa AM. Relatórios Científicos e Técnicos: Efeito da conservação de gónadas em estudos de fecundidade e de maturação. Lisboa: IPIMAR; 2003. (Série Digital; no. 4).

Dei Tos C, Gomes LC, Agostinho AA, Batista RP. Age, growth, mortality and yield per recruit of the dourado Salminus brasiliensis, Corumbá Reservoir, Goiás State, Brazil. Neotrop Ichthyol. 2009; 7(2):223-30.

Fernandes R, Agostinho AA, Ferreira EA, Pavanelli CS, Suzuki HI, Lima DP, Gomes LC. Effects of the hydrological regime on the ichthyofauna of riverine environments of the Upper Paraná River floodplain. Braz J Biol. 2009; 69(2, Suppl.):669-80.

Freitas TMS, Souza JBS, Prudente BS, Montag LFA. Lenghtweight relationship in ten species from the Nhamundá River, the Amazon basin, Brazil. Acta Amazonica. 2017; 47(1):75-78.

Freitas LJ, Prado PS, Arantes FP, Santiago KB, Sato Y, Bazzoli N, Rizzo E. Reproductive biology of the characid dourado Salminus franciscanus from the São Francisco River, Brasil. Anim Reprod Sci. 2013; 139(1-4):145-54.

Froese R. Cube law, condition factor and weight-length relationships: history, meta-analysis and recommendations. J Appl Ichthyol. 2006; 22(4):241-53.

Froese R, Pauly D, editors. FishBase. World Wide Web electronic publication [internet]; 2015 [cited 2016 Sep 20]. Available from: http://www.fishbase.org/

Froese R, Tsikliras AC, Stergiou KI. Editorial note on weight-length relations of fishes. Acta Ichthyol Piscatoria. 2011; 41(4):261-63.

Giarrizzo T, Bastos D, Andrade M. Length-weight relationships for selected fish species of Rio Trombetas Biological Reserve: a reference study for the Amazonian basin. J Appl Ichthyol. 2011; 27(6):1422-24. 
Gonçalves TL, Bazzoli N, Brito MFG. Gametogenesis and reproduction of the matrinxã Brycon orthotaenia (Günther, 1864) (Pisces: Characidae) in the São Francisco River, Minas Gerais, Brazil. Braz J Biol. 2006; 66(2A):513-22.

Goulding M. The fishes and the forest: explorations in Amazonian natural history. Berkeley: University of California Press; 1980.

Grimm AM, Ferraz SET, Gomes J. Precipitation anomalies in Southern Brazil associated with El Niño and La Niña events. J Clim. 1998; 11(11):2863-80.

Lima AC, Agostinho CS, Sayanda D, Pelicice FM, Soares AM, Monaghan KA. The rise and fall of fish diversity in a Neotropical river after impoundment. Hydrobiologia. 2016; 763(1):207-21.

Lima Junior SE, Cardone IB, Goitein R. Determination of a method for calculation of allometric condition factor of fish. Acta Sci. 2002; 24(2):397-400.

Lowe-McConnell RH. The fishes of the Rupununi savanna district of Britsh Guiana, Part 1. Ecological groupings of fish species and effects of the seasonal cycles on the fish. J Linn Soc London, Zool. 1964; 45(304):103-44.

Lowe-McConnell RH, editors. Ecological studies in tropical fish communities. Cambridge; New York; Melbourne: Cambridge University Press; 1987. (Cambridge Tropical Biology Series).

Machado C. Aspectos reprodutivos do dourado Salminus brasiliensis (Cuvier, 1816) (Teleostei, Characidae) na região do Alto rio Uruguai, Brasil. [MSc Dissertation on the Internet]. Florianópolis: Universidade Federal de Santa Catarina; 2003 [cited 2016 jul 06]. Available from: Repositório Institucional da UFSC. https:// repositorio.ufsc.br/xmlui/handle/123456789/86588

Marques AAB, Fontana CS, Vélez E, Bencke GA, Schneider M, Reis RE, organizers. Lista das espécies da fauna ameaçadas de extinção no Rio Grande do Sul: Decreto $\mathrm{n}^{\circ}$ 41.672, de 11 de junho de 2002. Porto Alegre: FZB/MCT PUCRS/PANGEA; 2002. (Publicações Avulsas FZB; no. 11).

Morais Filho MB, Schubart O. Contribuição ao estudo do dourado (Salminus maxillosus Val.) do Rio Mogi Guassu (Pisces, Characidae). São Paulo: Ministério da Agricultura, Divisão do Caça e Pesca; 1955.

Munro AD, Scott AP, Lam TJ. Reproductive seasonality in teleosts: environmental influences. Boca Raton; Florida: CRC Press; 1990.

National Oceanic and Atmospheric Administration (NOAA). Historical El Nino/ La Nina episodes (1950-present) [Internet]. Maryland: National Weather Service; 2015 [cited 2016 Jul 5]. Available from: http://www.cpc.ncep.noaa.gov/products/ analysis_monitoring/ensostuff/ensoyears.shtml

Nunes DMF, Magalhães ALB, Weber AA, Gomes RZ, Normando FT, Santiago KB et al. Influence of a large dam and importance of an undammed tributary on the reproductive ecology of the threatened fish matrinxã Brycon orthotaenia Günther, 1864 (Characiformes: Bryconidae) in southeastern Brazil. Neotrop Ichthyol. 2015; 13(2):317-24.

Oliveira AG, Suzuki HI, Gomes LC, Agostinho AA. Interspecific variation in migratory fish recruitment in the Upper Paraná River: effects of the duration and timing of floods. Environ Biol Fishes. 2015; 98(5):1327-37.

Pisciottano G, Díaz A, Cazes G, Mechoso CR. El Niño-Southern Oscillation impact on rainfall in Uruguay. J Clim. 1994; 7(8):1286-302.
Reynalte-Tataje DA, Hermes-Silva S, Silva PA, Bialetzki A, Zaniboni-Filho E. Locais de crescimento de larvas de peixes na região do alto rio Uruguai (Brasil). In: Zaniboni-Filho E, Nuñer APO, editors. Reservatório de Itá: Estudos ambientais, desenvolvimento de tecnologia e conservação da ictiofauna. Florianópolis: Editora da UFSC; 2008. p.159-193.

Reynalte-Tataje DA, Nuñer AP, Nunes MC, Garcia V, Lopes CA, Zaniboni-Filho E. 2012. Spawning of migratory fish species between two reservoirs of the upper Uruguay River, Brazil. Neotrop Ichthyol. 2012; 10(4):829-35.

Ribolli J, Hoeinghaus DJ, Johnson JA, Zaniboni-Filho E, Freitas PD, Galetti Júnior PM. Isolation-by-time population structure in potamodromous Dourado Salminus brasiliensis in southern Brazil. Conserv Genet. 2016; 18(1):67-76.

Sartori MDGB. A dinâmica do clima do Rio Grande do Sul: indução empírica e conhecimento científico. Terra livre. 2003; 1(20):27-49.

Sturges HA. The choice of a class interval: Case I. Computations involving a single series. J Am Stat Assoc. 1926; 21(153):65-66.

Vazzoler AEAM. Biologia da reprodução de peixes teleósteos: teoria e prática. Maringá: Eduem; 1996.

Veregue AML, Orsi ML. Biologia reprodutiva de Astyanax scabripinnis paranae (Eigenmann) (Osteichthyes, Characidae), do ribeirão das Marrecas, bacia do rio Tibagi, Paraná. Rev Bras Zool. 2003; 20(1):97-105.

Villacorta-Corrêa MA, Saint-Paul U. Structural index and sexual maturity of tambaqui Colossoma macropomum (Cuvier, 1818) (Characiformes: Characidae) in Central Amazon, Brazil. Rev Bras Biol. 1999; 59(4):637-52.

Villares Júnior GAV. Ciclo Reprodutivo de Salminus hilarii Valenciennes, 1850 (Ostariophysi, Characidae) em um rio da região Sudeste do Brasil, SP. Revista Vozes dos Vales. 2014; (6):1-15.

Welcomme RL. Fisheries ecology of floodplain rivers. London; New York: Longman; 1979.

Winemiller KO. Patterns of variation in life history among South American fishes in seasonal environments. Oecologia, 1989; 81(2):225-41.

Winemiller KO. Seasonality of reproduction by liverbearing fishes in tropical rainforest streams. Oecologia. 1993; 95(2):266-76.

Winemiller KO, Jepsen DB. Effects of seasonality and fish movement on tropical river food webs. J Fish Biol. 1998; 53(Suppl. A):267-96.

Zaniboni-Filho E, Schulz UH. Migratory fishes of the Uruguay River. In: Carolsfeld J, Harvey B, Ross C, Baer A, editors. Migratory Fishes of South America: biology, fisheries and conservation status. Victoria, Canada: World Fisheries Trust; International Development Research Centre; World Bank; 2003. p.161-198.

Zardo EL, Behr ER. Population structure and reproductive biology of Loricariichthys melanocheilus Reis \& Pereira, 2000 (Siluriformes: Loricariidae) in the rio Ibicuí, Brazil. Neotrop Ichthyol. 2015; 13(2):371-82. 